KEMAS 15 (3) (2020) 441-449
Jttp://journal.unnes.ac.id/nju/index.php/kemas

\title{
Developing Reproductive Health Communication in Early Marriage
}

\author{
$\mathrm{Najib}^{1 \bowtie}$, Alfiana Ainun $\mathrm{Nisa}^{2}$, Efa Nugroho $^{2}$, Evi Widowati ${ }^{2}$, Chia-En Yang ${ }^{3}$ \\ ${ }^{1}$ Indonesian Population and Family Planning Board (BKKBN) of Central Java, Indonesia \\ ${ }^{2}$ Department of Public Health, Universitas Negeri Semarang, Indonesia \\ ${ }^{3}$ National Pingtung University of Science and Technology, Taiwan (R.O.C)
}

\section{Article Info}

Article History:

Submitted November 2019

Accepted February 2019

Published March 2020

Keywords:

Reproductive Health,

Communication, Early

Marriage, Contraception

DOI

https://doi.org/10.15294/

kemas.v15i3.23880

\begin{abstract}
Adolescent fertility is an important health and social problem because it is related to the level of morbidity and mortality of mothers and children. The results of the 2017 IDHS show that $7 \%$ of women aged $15-19$ are already mothers, $5 \%$ have given birth, and $2 \%$ are pregnant with their first child. The data shows that adolescents are already sexually active, but still have an understanding of low reproductive health. The purpose of this study was to determine the effectiveness of community-based health communication models that developed to improve access to information and public knowledge related to contraceptive methods in young married couples in Rembang Regency in 2019. This research used Research and Development design with a quasi-experimental data collection method. The population in this study were adolescents who married at a young age in Rembang District, while the sample was adolescents who married young in Sedan and Kragan villages (intervention group), Menoro and Ngasinan (control group). Quantitative data analysis uses univariate, bivariate, and multivariate, while for qualitative data use grounded theory. The effectiveness test showed significant data for knowledge ( $p$ $=0,000)$, attitudes $(\mathrm{p}=0.003)$, access to information $(0.012)$, preferences $(\mathrm{p}=0.001)$, and access to contraception $(\mathrm{p}=0,000)$. It can be concluded that the community-based health communication model can improve knowledge, attitudes, access to information, preferences, and access related to contraception in early married couples.
\end{abstract}

\section{Introduction}

The shape of the population pyramid owned by Indonesia is similar to the population pyramid in most developing countries, which reflects the transitional age structure. Countries with this population structure reflect the decline in fertility rates in the region. Factors that can cause changes in the condition of the population structure in an area are the population growth rate (LPP) along with the components that influence it, namely fertility, mortality, and migration. Decreased fertility and infant mortality rates will have an impact on changes in age structure, such as the population of children under five (0-4 years) and the age of children (5-9 years) which are increasingly shrinking in number, while adolescents (10-19 years) and population ages adults (20-29 years) will tend to increase.

Indonesia experienced a demographic bonus in 2020-2035 as a result of the demographic transition process that developed for the success of the family planning program that was able to reduce fertility and improve the quality of health and the success of other development programs. Understanding the meaning of demographic bonuses, it is people who are young or younger generation who are players in this demographic bonus. In their hands the direction and progress of Indonesia will be determined, whether it really becomes a "threat" or "opportunity". That is, this becomes 
a threat when this young generation is not prepared seriously, correctly, in a planned manner, and its implementation is guarded carefully and responsibly.

The results of the IDHS showed that the trend of adolescent fertility in Indonesia was declined. In 1997, around $12.2 \%$ of adolescents had raised a family, 9.4\% had given birth to a child and $2.7 \%$ were pregnant with their first child. The 2002/2003 IDHS showed a decrease to $10.4 \%$ of adolescents who had given birth or were pregnant with their first child. In 2007, $6.6 \%$ of adolescents had given birth and $1.9 \%$ of adolescents were pregnant with their first child. Meanwhile, the 2012 IDHS results showed an increase in adolescent fertility, the percentage of female adolescents aged 15-19 who had given birth and became pregnant with their first child was $10 \%$.

Various local and international studies had shown that socio-demographic characteristics of adolescents had a relationship with adolescent fertility. One of the main factors is early marriage. As many as $7.4 \%$ of women in Indonesia marry at the age of 1519 years and $49.9 \%$ of women get married at the age of 20-24 years. The first age of women having sex at the age of 15 years was $3.2 \%$, age 18 years was $22.60 \%$, age 20 years was $39.90 \%$, and age 22 years was $48 \%$. Women who live in rural areas tend to have marriages and first sexual relations at a younger age than women in urban areas. The median age of marriage and first sex increases with increasing knowledge and economy (SRPJMN, 2017).

The high rate of early marriage raises various health problems. Pregnant women under the age of 18 have a $35 \%$ to $55 \%$ higher risk of having a baby with a low birth weight baby (LBW) compared to mothers over the age of 19 years. The infant mortality rate is $60 \%$ higher in mothers who are under 18 years of age. Children of young mothers have a $28 \%$ greater risk of death under 5 years. This illness and death are caused by poor maternal nutrition, physical and psychological immature mothers, lack of community access and access to reproductive health services and a high risk of infectious diseases (Nour, 2019).

In Indonesia the percentage of women in the age group of 15-19 years who did not use contraception reached $51.9 \%$. In addition, men's participation in the use of contraceptives is still very minimal. Based on preliminary reports of the 2012 IDHS, in Indonesia only 2\% of married couples use contraceptives for men. In addition, in Rembang District the percentage of active contraceptive use is $80.2 \%$ while couples of childbearing age who do contraceptive use only 38.3\% (DKK Rembang, 2014).

The rate of early marriage in Central Java is $19.92 \%$. In 2016 there were at least 30,128 submissions for dispensations for early marriage under 16 years with various factors underlying them. According to SRPJMN data (2017), as many as $22.1 \%$ of teenagers in Central Java do not know the impact of early marriage. Rembang is a rural area in Central Java with a high rate of arly marriage and teenage pregnancy (DKK Rembang, 2017).

The results of research conducted by Afilia concluded that there was a significant relationship between adolescent attitudes with contraceptive use in adolescents and positive attitudes towards contraceptive use (63.3\%). The number of adolescents who are positive in using contraception therefore adolescents need to be directed and given reproductive health education., comprehensive and integrated sexual education and reproductive health services so as not to conflict with community norms, values and beliefs. (Afrilia, E. M., 2012)

Research conducted by Akib shows that factors related to the use of family planning contraception services in fertile age couples are age, education, information provision, husband's support and those who do not have a relationship between the use of family planning contraception services in fertile age couples, namely knowledge and work. It is recommended that health workers provide information about the use of contraceptive contraception services in fertile age couples to increase knowledge about the use of contraceptives (Akib, 2019)

The problem in this study is how to increase the use of modern contraception in young married couples. Based on these problems, researchers sought to develop a community-based health communication intervention program using the principle of community empowerment. The principles of community empowerment include: 
1). Developing community potential, 2) Community contribution in health development, 3) Developing mutual cooperation, 4) Working together with the community, 5) Community-based Information and Education Communication, 6) Partnerships, and 7) Decentralization.

\section{Methods}

Research and development according to Gay (1990) is a business or activity to develop an effective product, and not to test the theory. This study examines developing a model of community-based health communication interventions related to contraceptive methods in young married couples. The design of this study can be seen in the following figure:

For retrieval of research data using quasiexperimental with control design. Baseline activities will be carried out in 4 villages, but only 2 villages will receive intervention. Then endline activities will also be carried out again in 4 villages. The study will also make it possible to observe the long-term effects of interventions after two months without any intervention that has passed in 4 villages.

Qualitative data collection is carried out by means of Focus Group Discussion (FGD) which will involve participants as follows: Young married couples ( 4 boys and 4 girls), Family Planing reach staff ( 2 people), Representatives of religious leaders (2 people), BKKBN Representative (2 people), Health center representatives (2 people), and Representative of Health Service (2 people).

Quantitative surveys will be conducted on young married couples in the intervention and control villages: Kragan Village (30 people), Sedan Village (30 people), Rembang Village (30 people), and Sarang Village (30 people).

The baseline activity will consist of quantitative and qualitative methods. For the questionnaire, participants will be given a copy of the questionnaire and asked to complete it at the agreed time. Four participants will be selected by the research team for the FGD. Participants will be randomly selected from the attendance list. The discussion will be led by a research team. This FGD will be guided by a series of pre-determined questions that cover issues regarding reproductive health and contraception.

Endline activities use questionnaires and FGD guidelines that are the same as the baseline stage. Endline will be done after the intervention to see how the intervention model works in the community. The results will be analyzed compared to the control villages.

The collected data will be analyzed using descriptive statistics, inferential statistics, and qualitative descriptive approaches. The results of the FGD and in-depth interviews were qualitative data. Therefore, the data will be analyzed using a qualitative descriptive approach. The majority of data from

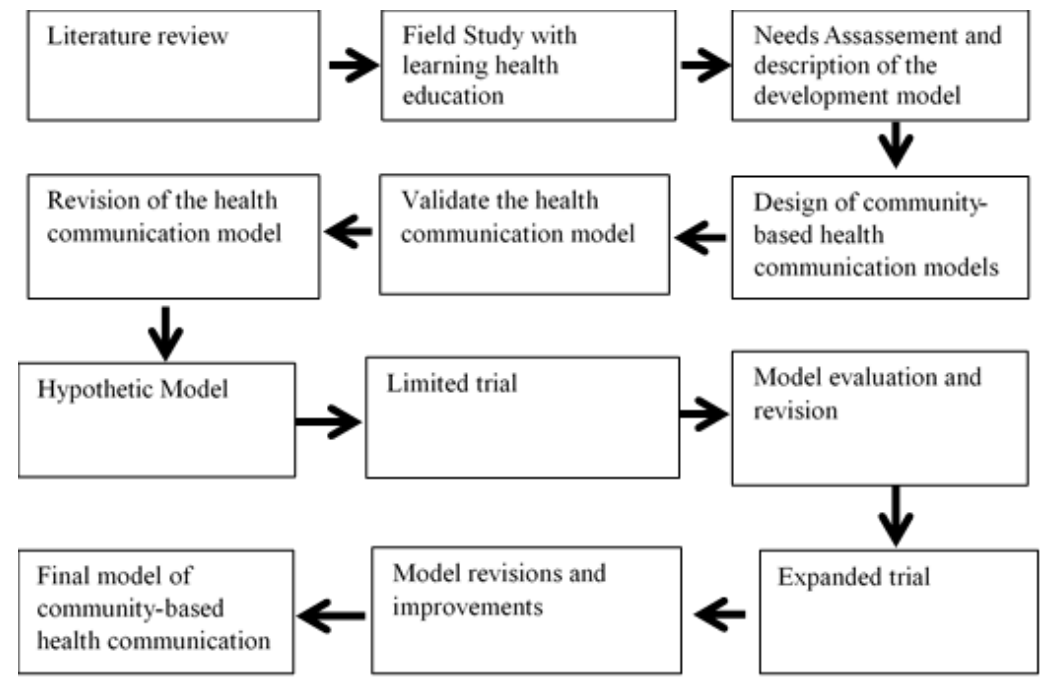

Figure 1. Design of RnD study 
questionnaires will be entered into excel spreadsheets and analyzed through descriptive statistics and inferential statistics.

\section{Result and Discussion}

From the figure 2 it is known that the causes of these problems are due to adolescent factors, parental factors, community cultural factors, and economic factors. The low level of knowledge of adolescents, parents, and the community is thought to be a major factor in the high reproductive health problems in adolescents including the low use of contraception in couples of childbearing age. In addition, there is also a culture that considers contraceptive use to conflict with religious values.

From the results of the study found the potential of social capital to overcome these problems. Social capital is a resource that is owned by the community in the form of norms or values that facilitate and build cooperation through a harmonious and conducive network of interaction and communication. Thus the health communication model that is suitable is developed using a social bounding approach. Social bounding is, the type of social approach with the characteristics of a strong bond (the existence of social glue) in a social system. Social bounding is generally in the form of values, culture, perceptions, and traditions or customs.

There are three elements, components, resources and important elements in the development of a community-based communication model, namely trust, values and norms and networks. Trust is the hope that grows in a society that is shown by the existence of honest, orderly, and cooperative behavior based on shared norms. Values and norms are the basic things found in the process of social interaction. Values and norms refer to how individuals should act in society. Norms are formed through tradition, history, charismatic figures who build a procedure for the behavior of a person or a group of people, in which rules will arise which can govern personal interests and group interests. The network is formed because it comes from the same region, similar political or religious beliefs, genealogical relationships, and others. The formation of community networks for model development needs to be organized in a container with special treatment.

The models developed in this study are health communication through the Forum Anak Desa (Village Children Forum), Komisi Perlindungan Anak Desa (Village Children Protection Commission), Peer Educators in Schools, and Association for Small Business Improvement. Activities in Forum Anak Desa are in the form of Posyandu Remaja, Reproductive Health Discussion for Boys, and for Girls. Activities in the Komisi Perlindungan Anak Rembang are in the form of a series of discussions about the pattern of adolescent care, adolescent problems, serve complaints

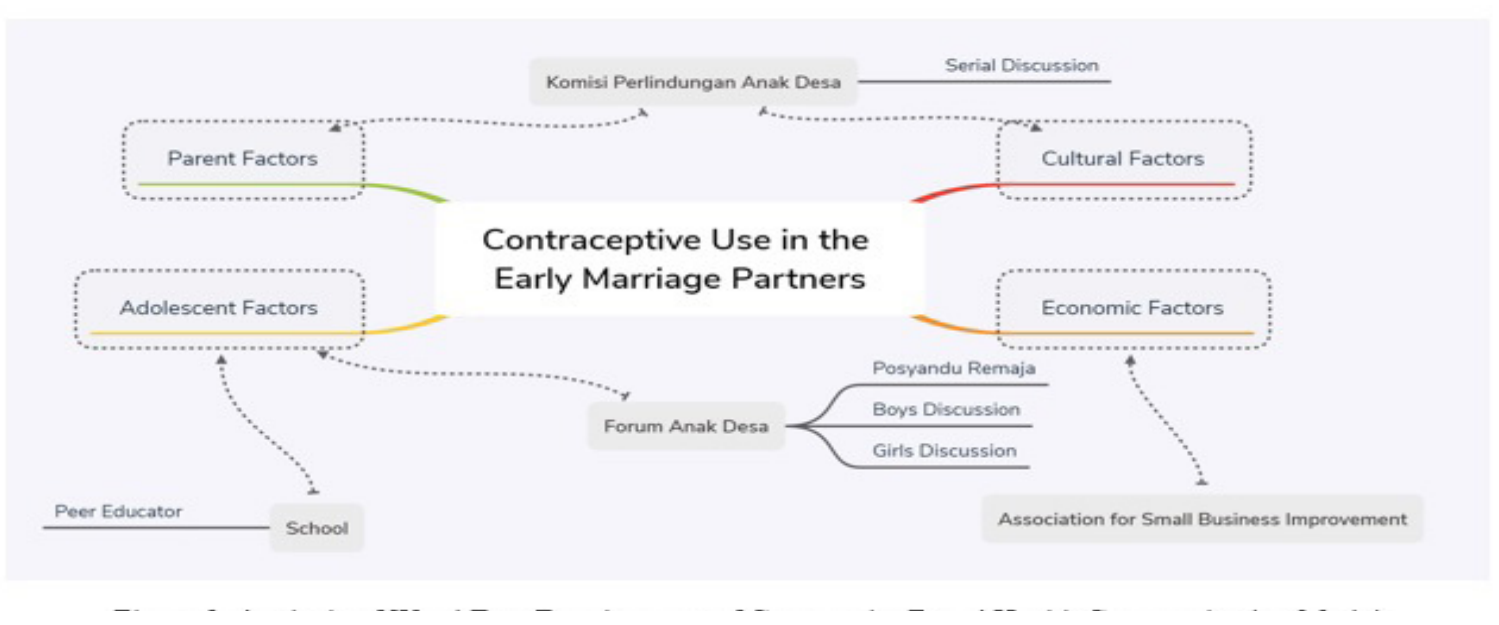

Figure 1. Qualitatife Analysis of Contraceptive Use in the Early Marriage Partners 
and services if there are problems experienced by adollescent. Peer educator activities in the school include the selection of peer educators, counseling, education, and group discussions. For economic problems carried out with business development utilizing existing local potential

For the analysis of quantitative results using the Wilcoxon test. From the statistical test results obtained data knowledge (pvalue $=0,000$ ), attitudes (pvalue $=0.003$ ), access to information (0.12), preferences (0.001), and access to contraception $(0,000)$.

\section{Knowledge}

The test statistics section shows the Wilcoxon test results, based on the Wilcoxon test it is known that the significance value is $0,000(\mathrm{p}<0.05)$ which means there is an increase in the knowledge score obtained by respondents before and after the intervention is given. This shows that the effective communitybased communication model is used to increase respondents' knowledge.

Good respondent's knowledge about contraception will influence them in choosing the method / contraception that will be used including freedom or freedom of choice, compatibility, whether or not effective choice, comfort and safety, also in choosing a more appropriate place of service because of better insight, so that awareness they are high to continue to take advantage of service.

This is in line with previous research which shows that there is a relationship between knowledge and the use of an IUD ( $p$ value $=0.036$ ). According to him, knowledge occurs after people sensing a certain object. Sensing occurs through the five human senses, namely the sense of sight, hearing, smell, taste and touch. Most of the knowledge is obtained through the eyes and ears. Knowledge or cognitive is a very important domain in shaping action (Pitriani, 2015). In line with previous research, based on the results of the chi square statistical test showed that there was no significant relationship between maternal knowledge about contraceptive methods with the selection of hormonal and nonhormonal contraception in Majalaya Health Center in Bandung Regency with a p-value of $0.423>0.05$ (Hayati, Maidartati, \& Komar,
2017). In contrast to other studies which state that knowledge is not related to the use of contraceptive contraception ( $p=0.448)$. The results of his research said that fertile age couples who have sufficient knowledge will choose long-term method of contraception because family planning participants more often get information from various sources such as social media, electronics, magazines and so on and more use of contraceptive services and couples of fertile age who the level of knowledge is mostly lacking using contraceptives and utilizing 25 (62.5\%), this is due to the lack of knowledge about contraception is limited and only on contraceptives used in couples of childbearing age. While couples of childbearing age who have sufficient knowledge and do not utilize contraceptive services can be caused by other factors where the husband does not support using these contraceptives (Akib, 2019).

\section{Attitude towards Behaviour}

Based on Wilcoxon test known significance value of $0.003(\mathrm{p}<0.05)$ which means that there are differences in attitudes obtained by respondents before and after the intervention was given. At the initial pretest the respondents' attitudes toward negative contraception, after community-based communication interventions occurred, the assertion became open and positive.

Respondents' attitudes are influenced by knowledge, education, economy, social status, family, religion, and values. Knowledge of contraception is actually intended to make teenage respondents more permissive to premarital sexual relations because teenagers now have good knowledge and attitude towards contraception. Respondents' attitudes like or dislike the use of contraceptives. This attitude is often obtained from one's own experience or from imitating others who are closest.

Other studies from the results of Bivariate Analysis that have been done using chi square test obtained p-value of 0.002 , it can be concluded that the $\mathrm{p}$-value $<\alpha$ so that $\mathrm{Ha}$ is accepted which means there is a relationship between adolescent attitudes with the use of contraception in street children in Pamulang Permai. In this study adolescent attitudes often refer to peer experiences which are not 
necessarily true and healthy experiences. Because the influence of peers is greater in bad practice, they will also follow it and eventually their reproductive health practices are bad (Afrilia \& Cahyanti, 2012). In line with previous studies with a $\mathrm{p}$ value of 0.034 which means there is a relationship between the attitudes of respondents with the behavior of using contraceptives. Inadequate behavior in the use of contraceptives is found in the group of mothers' attitudes toward family planning that do not support by $57.1 \%$, compared to the group's attitude of mothers towards family planning that supports by $31.3 \%$ (Huda, Widagdo, \& Widjanarko, 2016).

The results of research conducted by James B. Weaver, revealed a unique pattern of linkages between the type of health information sought (health, disease, etc.) and self-assessment of health among adult Internet users in the state of western Washington. This association shows that various attitudes towards health can underlie Health Information Seeking Behavior, a phenomenon that is often overlooked in previous research.( James B. Weaver, 2010)

\section{Information Access}

Based on Wilcoxon test known significance value of $0.012(\mathrm{p}<0.05)$ which means there is an increase in access to information obtained by respondents before and after the intervention was given.

The number of sources of information about contraception is quite varied with the minimum number being two and the maximum is six sources of information. The number of sources of information obtained by women of childbearing age is significantly positive correlation with knowledge. This means that the more amount of information, the better the knowledge about contraception.

Previous research shows there is a relationship between family planning staff support in the form of providing information with the choice of non hormonal MKJP contraception $(\mathrm{p}$ value $=0.049)$. The results showed that the support of health workers in the form of providing information related to the use of Non-Hormonal MKJP. Health workers play a role in providing information, counseling and explaining about the main contraceptive tools regarding Non-Hormonal
MKJP (Setiasih, Widjanarko, \& Istiarti, 2016). In line with previous research showing the relationship between providing information and using contraceptive services $(\mathrm{p}=0.036)$. According to him, information obtained from health workers, social media, electronic media, books, advertisements or newspapers and as a source of information obtained. This is the same as research conducted by Tatik Kusyanti, that information about reproductive health through film media can double the participation of teenage married couples in using modern contraception, with chi square results ( $\mathrm{p}=$ 0.015), RR: 2.33 (Tatik Kusyanti, 2016).

KB staff play a role in providing information, counseling and explanation of contraceptives for acceptors who are still hesitant in using contraceptives and decide to use these contraceptives on the advice of family planning officers (Akib, 2019). Barriers to family planning in an effort to increase the use of contraception include: the provision of family planning understanding to the community is still not well implemented, Providing information and conducting coaching is not well implemented (Atang Sudrajat, 2015). In contrast to other studies which show that there is no relationship between access to information with the intention of using contraceptives. The results of this study indicate that the largest percentages (96.7\% and $93.3 \%$ ) that are sources of contraceptive information are friends / neighbors and family. More than two-fifths of respondents $(45.0 \%)$ trust the information provided by midwives or doctors who are considered as someone based on their work, education and experience. In addition, almost all respondents (95.0\%) received information about the risk of contraception by their information sources. Almost all respondents $(98.3 \%$ and $96.7 \%)$ knew of injection contraceptives and pills (Putri \& Simanjuntak, 2013).

\section{Preference}

Based on Wilcoxon test known significance value of $0.001(\mathrm{p}<0.05)$ which means Ho is rejected and Ha is accepted, thus it can be concluded that there are differences in preferences obtained by respondents before and after given the intervention.

Respondents who are trying their 
contraception for the first time will consider the method of installation and its side effects. Respondents will choose a contraceptive method that is easy and not frightening. While in terms of side effects it is also important to consider by respondents. Respondents were worried about the side effects that would be experienced if using certain contraceptives. Safe contraception does not mean that the respondent is using it immediately, but it must also be seen in terms of cost. Although long-term contraception, such as an IUD, is considered the safest, the price of a one-time installation is considered expensive by some respondents. This indicates that contraception is a new requirement that must be met to control fertility.

The low prevalence of contraception reflects the desire to get pregnant or the inability to access family planning services, so that contraceptive needs are not met (unmet need) (Rizkianti, Amaliah, \& Rachmalina, 2017).

\section{Contraceptive Use}

Based on the Wilcoxon test it is known that the significance value is $0,000(\mathrm{p}<0.05)$ which means that $\mathrm{Ho}$ is rejected and $\mathrm{Ha}$ is accepted, thus it can be concluded that there are differences in Accessing Contraception obtained by respondents before and after intervention is given.

The availability of health services is about the completeness of contraceptives, rooms, and transportation to the place of health facilities (infrastructure) that are used to perform health services, making it easier or convincing for patients to seek treatment or consultation. If the facilities and infrastructure are comfortable and the tools are complete, sterile and varied, there will also be a lot of community interest in using contraceptives. In line with research which shows that the availability of contraceptive products in the local service environment plays an important role in women's demand for and use of contraceptive methods. by estimating population density with health services and calculating distance to facilities and the amount of contraceptive supply. Differences in regional conditions must be considered when attempting to improve access to contraception.(Skiles MP, Cunningham, 2015)

In line with previous research which shows there is a relationship between the factors of access to services with the use of the IUD (p value 0.0005 ). Accessibility factors for services that are difficult in the case group of 5,268 times for not using an IUD compared to KB GRT acceptors who are easy to access IUD services (Setiowati, 2010). In contrast to other studies that show that accessibility constraints do not affect the choice of contraceptive methods (pvalue $=0.438$ ). Distance to family planning services is one of the factors that can influence the use of contraceptives. Simple regression statistical test results found that there is no effect of accessibility constraints with the selection of contraceptive methods, with a $\mathrm{p}$ value $=0.438$. Barriers to accessibility have no effect in the choice of contraceptive methods because the proximity to health facilities will make it easier for family planning acceptors to reach and access the services provided. The closer the KB services (there are no accessibility barriers), it will make it easier for family planning acceptors to access family planning services (Septalia \& Puspitasari, 2016).

\section{Conclusion}

The model developed in this study is community-based health communication. The communication model is through the formation of the Village Children Forum (FAD). Village children's forum activities include the Posyandu Remaja, reproductive health reproductive education for boys and girls. This model also approaches adults by forming a Village Children Protection Commission (KPAD). One of KPAD's activities is reproductive reproductive health program for adult groups of men and women. Test the effectiveness of the model showed significant results. Effective models to increase knowledge $(\mathrm{p}=0,000)$, attitudes $(\mathrm{p}=0.003)$, access to information (0.012), preferences $(\mathrm{p}=0.001)$, and access to contraception $(\mathrm{p}=0,000)$.

\section{Reference}

Afrilia, E. M., \& Cahyanti, Y. D. (2012). Hubungan Sikap Remaja dengan Penggunaan Kontrasepsi pada Anak Jalanan di Pamulang Permai. Jurnal JKFT:Universitas Muhammadiyah Tangerang, 2, 8-13.

Akib, A. (2019). Faktor yang Berhubungan dengan Pemanfaatan Pelayanan Alat Kontrasepsi KB pada Pasangan Usia Subur di Puskesmas 
Tamalanrea Kota Makassar 2019. [JFS] Jurnal Farmasi Sandi Karsa, 5(1), 71-83.

Atang Sudrajat (2015). Kinerja Tenaga Penggerak Desa Dalam Upaya Meningkatkan Keikutsertaan Pemakaian Kontrasepsi Metode Operasi Pria (MOP) di Desa Batumalang Kecamatan Cimerak Kabupaten Pangandaran. Moderat: Jurnal Ilmiah Ilmu Pemerintahan, 1(2), 287-297

BKKBN. (2017). Survei Kependudukan, Keluarga Berencana, Kesehatan Reproduksi Remaja dan Pembangunan Keluarga di Kalangan Remaja Indonesia: Jakarta

Departemen Agama Kabupaten Rembang. (2017). Data Kasus Pernikahan dini Kabupaten Rembang tahun 2014. Rembang: Departemen Agama Kabupaten Rembang

DKK Rembang. (2017). Profil Kesehatan Kabupaten Rembang tahun 2014. Rembang: Dinkes Kabupaten Rembang

Handayani, O. W. K., Wiranti, I., Raharjo, B. B., \& Nugroho, E. (2019). The Reproduction Health Behavior of High School Teenagers in Semarang, Indonesia. The Open Public Health Journal, 12(1).

Hayati, S., Maidartati, \& Komar, S. N. (2017). Hubungan Pengetahuan Ibu Tentang Metode Kontrasepsi Dengan Pemilihan Kontrasepsi ( Studi Kasus : Puskesmas Majalaya ). Jurnal Keperawatan BSI, V(2), 155-163.

Huda, A. N., Widagdo, L., \& Widjanarko, B. (2016). Faktor-Faktor yang Berhubungan dengan Perilaku Penggunaan Alat Kontrasepsi pada Wanita Usia Subur di Puskesmas Jombang-Kota Tangetang Selatan. JURNAL KESEHATAN MASYARAKAT, 4(1), 461469.

James B. Weaver, Darren Mays, Stephanie S. Weaver, Gary L Hopkins, Dogan Eroglu \& Jay M Bernhardt. (2010). Health Information;Seeking Behaviour, Health Indicators and Health Risk. American Journal of Public Health. 100 (8): 1520-1525.

Linda Suwarni, Selvian (2015) Inisiasi Seks Pranikah Remaja Dan Faktor Yang Mempengaruhi. JURNAL KESEHATAN MASYARAKAT, 10(2): 169-177.

Nour, N. M. (2019). Child Marriage: A Silent Health and Human Right Issue. Women's Health in the Developing World, 2(1): 51-56

Nugroho, E., Shaluhiyah, Z., Purnami, C. T., \& Kristawansari, K. (2017). Counseling Model Development Based on Analysis of Unwanted Pregnancy Case in Teenagers. KEMAS: Jurnal Kesehatan Masyarakat, 13(1), 137-144.

Nugroho, E., Nisa, A. A., Rahayu, F. D., Hermawan,
D. Y., \& Najib, N. (2019). Development of Community-Based Health Communication Models in the Early Marriage Partners. In 5th International Conference on Physical Education, Sport, and Health (ACPES 19). Atlantis Press.

Pitriani, R. (2015). Hubungan Pendidikan, Pengetahuan dan Peran Tenaga Kesehatan dengan Penggunaan Kontrasepsi Intra Uterine Device ( IUD ) di Wilayah Kerja Puskesmas Rawat Inap Muara Fajar Pekanbaru. Jurnal Kesehatan Komunitas, 3(1), 25-28.

Putri, A. M. L., \& Simanjuntak, M. (2013). Persepsi Risiko dan Niat Penggunaan Alat Kontrasepsi. Jur. Ilm. Kel. \& Kons., 6(3), 199-205.

Raharjo, B. B., Nugroho, E., Cahyati, W. H., Najib, N., \& Ainun, A. (2019). Proximate Determinant of Adolescents Fertility in Central Java. KEMAS: Jurnal Kesehatan Masyarakat, 15(1).

Rizkianti, A., Amaliah, N., \& Rachmalina, R. (2017). Penggunaan Kontrasepsi pada Remaja Perempuan Kawin di Indonesia (Analisis Riskesdas 2013). Buletin Penelitian Kesehatan, 45(4), 257-266.

Septalia, R., \& Puspitasari, N. (2016). Faktor yang Memengaruhi Pemilihan Metode Kontrasepsi. Jurnal Biometrika Dan Kependudukan, 5(2), 91-98.

Setiasih, S., Widjanarko, B., \& Istiarti, T. (2016). Analisis Faktor-faktor yang Mempengaruhi Pemilihan Metode Kontrasepsi Jangka Panjang ( MKIP ) pada Wanita Pasangan Usia Subur ( PUS ) di Kabupaten Kendal Tahun 2013. Jurnal Promosi Kesehatan Indonesia, 11(2), 32-46.

Setiowati, T. (2010). Faktor-Faktor yang Berhubungan dengan Penggunaan Alat Kontrasepsi Rahim pada Akseptor KB Golongan Risiko Tinggi di Puskesmas Wilayah Kec. Cimahi Selatan Kota Cimahi Tahun 2008. Jurnal Kesehatan Kartika Stikes A. Yani, 1-11.

Skiles MP, Cunningham M, Inglis A, Wikes B, Hatch B, Bock A, Barden-O Fallon. 2015. The effect of access to contraceptive services on injectable use and demand for family planning in Malawi. Int Perspect Sex Reprod Health. 41(1):20-30

Tait AR, Voepel-Lewis T, Levine R (2015). Using digital multimedia to improve parents' and children's understanding of clinical trials. BMJ Journal Archives of Disease in Childhood, 100:589-593. 
Tatik Kusyanti, Hadyana Sukandar, Farid Husin (2016). Pendidikan Kesehatan dengan Media Film "Derita Tiada Akhir" Menggugah Pengantin Remaja dalam Menggunakan Kontrasepsi Modern. Jurnal Ners dan
Kebidanan Indonesia. 4 (3).

Titis Wahyuni. (2019). Faktor-Faktor Penggunaan Kontrasepsi Pada Wanita Usia Subur 15-19 Tahun Di Indonesia (Data Srpjmn 2017). Jurnal JKFT.4 (1) 